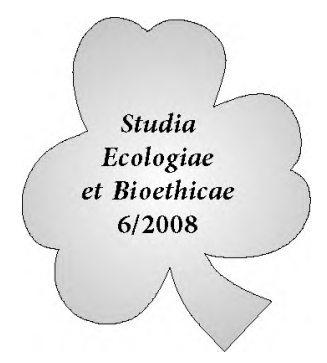

\title{
Wpływ czynników kulturowych na upadek cywilizacji grenlandzkich Wikingów
}

\section{Wprowadzenie}

Wzajemne oddziaływanie kultury i natury jest czymś oczywistym i niezaprzeczalnym. Wielu uczonych definiując kulturę odnosi ją do natury. Yehudi Cohen określa nawet kulturę jako przedłużenie fizjologii człowieka oraz najważniejsze narzędzie jego adaptacji i opanowania przyrody. ${ }^{1}$ Natomiast ujęcie kultury wg Roberta L. Carneiro bardziej akcentuje to, że kultura jest swego rodzaju pośrednikiem wprowadzonym przez czlowieka pomiędzy siebie i naturę, $w$ celu zapewnienia sobie bezpieczeństwa i przetrwania. ${ }^{2}$ Nie dziwi więc fakt, że analizując upadek cywilizacji grenlandzkich Wikingów należy pokazać wpływ ich kultury na środowisko naturalne, którego degradacja stała się jedną z głównych przyczyn ich zagłady. Wydaje się, że na ten upadek miały także wpływ wybory kulturowe Wikingów, które stały się bezpośrednią przyczyną ich niedostosowania do zachodzących zmian i w konsekwencji zaowocowały śmiercią tej cywilizacji.

Upadki cywilizacji są faktami potwierdzanymi licznymi wynikami badań uczonych. Istnieje wiele różnych koncepcji teoretycznych, które przedstawiają odmienne wizje tego, czym jest cywilizacja oraz jak należy rozumieć jej upadek. Joseph A. 囚ainter ${ }^{3}$ wskazuje, że współcześnie upadek/śmierć cywilizacji rozumie się jako istotną transformację jej cech lub zachowań, które charakteryzują ją jako byt kulturowy. Cechy te powinny być na tyle istotne, że stanowią o kształcie tego, co potocznie określamy „cywilizacją”, czyli kierunki w sztuce i architekturze, tradycje literackie i muzyczne oraz myśl filozoficzną i polityczną. Za taką właśnie koncepcją końca cywilizacji opowiadają się m.in. Arnold ఐoynbee i Oswald Spengler. Z tak rozumianą koncepcją „śmierci cywilizacji” nie zgadza się jednak

Por. Y. A. Cohen, Culture as Adaptation, [w:] Y. A. Cohen (red.), Man in Adaptation. The Cultural Present, Chicago: Aldine Publishing Company 1968, s. 40-60.

2 Por. R. L. Carneiro, Cultural adaptation, [w:] D. Sells (red.), International Encyclopaedia of the Social Sciences, t. 3, Macmillan 1968-1979, s. 551-554.

3 Por. J. A. 囚aInter, The Collapse of Complex Societies, Cambridge University Press 2004, s. 22-90. 
Pitirim Sorokin, który wskazuje na nieustanne zmiany zachodzące w każdej cywilizacji oraz na fakt, że „śmierć” jakiejś cywilizacji jest najczęściej początkiem nowej cywilizacji powstałej na gruzach poprzedniej. Nowa cywilizacja przejmuje wiele ze starej i, przynajmniej w pewnym zakresie, jest jej kontynuacją. Dyskusyjne jest także określenie samego momentu „śmierci” danej cywilizacji, bo proces ten jest zwykle długotrwały. ${ }^{4}$

Problemem jest także zdefiniowanie samej cywilizacji. Drudne jest podanie jednoznacznego kryterium odróżniającego społeczności „cywilizowane” od „niecywilizowanych". Opinie uczonych są w tym względzie podzielone. Shephard B. Clough definiuje cywilizację jako „osiągnięcia w zakresie estetyki i poszukiwań intelektualnych oraz sukces w kontroli nad środowiskiem naturalnym". Alfred Kroeber wskazuje, że cywilizacja powinna charakteryzować się obecnością wyższych wartości i form kulturowych. ${ }^{6} \mathrm{Z}$ kolei Matthew Melko określa cywilizację, jako wielką i złożoną kulturę. Wydaje się, że rozsądna jest propozycja Đaintera, by pomimo licznych różnic, uznać iż cywilizacja to system kulturowy złożonej społeczności. Natomiast cechy, które powszechnie uznaje się za właściwe społecznościom cywilizowanym, jak np. bogate tradycje artystyczne i literackie, są czynnikami społecznej, politycznej i ekonomicznej złożoności. \o właśnie owa złożoność leży u podstaw cywilizacji, ponieważ rozwinięta sztuka i literatura służy społecznym i ekonomicznym celom oraz klasom społecznym, które mogą istnieć tylko w społecznościach złożonych. Cywilizacja więc pojawia się wraz ze złożonością, istnieje dzięki niej i wraz z nią znika. Złożoność jest więc - wg 区aintera - podstawą cywilizacji, która $\mathrm{z}$ definicji zanika wraz z zanikiem złożoności. ${ }^{8}$

Niniejsze opracowanie opiera się na przykładzie społeczności Wikingów, ${ }^{9}$ którzy rozpoczęli kolonizację Grenlandii około roku 986 p.Ch.n. i przez około pięćset lat nieprzerwanie zamieszkiwali to nieprzyjazne człowiekowi terytorium. Wikingowie założyli dwie kolonie określane jako Kolonia Wschodnia i Zachodnia. ${ }^{10}$ Samo określenie jest mylące ponieważ terytoria te były od siebie oddalone o niemal $500 \mathrm{~km} \mathrm{w}$ kie-

4 Por. 冈amże, s. 40.

5 S. B. Clough, The Rise and Fall of Civilization, McGraw-Hill: New York 1951, s. 3.

6 Por. A. L. Kroeber, Configurations of Culture Growth, University of California Press: BerkeleyLos Angeles 1944, s. 8.

Por. M. Melko, The Nature of Civlizations, Porter Sargent: Boston 1969, s. 8.

8 Por. J. A. \aInTER, The Collapse of Complex Societies, dz. cyt., s. 41.

9 Panoramę badań nad społecznością Wikingów przedstawia Thomas McGovern podając jednocześnie obszerną bibliografię na ten temat. Por. 冈. McGovern, The Archaeology of the Norse North Atlantic, [w:] „Annual Review of Anthropology” 1990, Vol. 19, s. 331-351.

10 Kolonia Wschodnia była większa, została założona jako pierwsza już na początku osadnictwa $\mathbf{i}$ była zamieszkana przez caly okres 500 lat, prawdopodobnie aż do początku wieku XVI. Kolonia Zachodnia była znacznie mniejsza i opustoszała w drugiej połowie wieku XIV. Mapy obu kolonii zamieszczone w tym opracowaniu pochodzą z artykułu: History of Greenland zawartego w Wikipedii <http://en.wikipedia.org/wiki/History_of_Greenland> (Data dostępu 21.06.2008). 


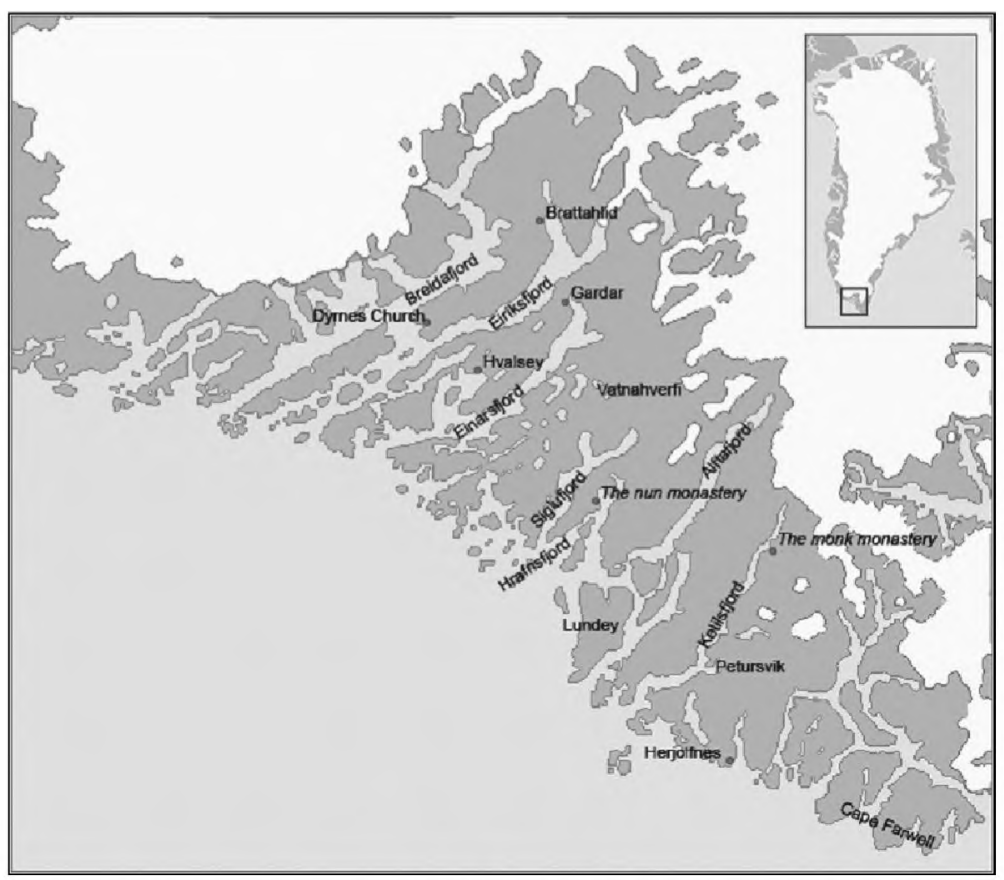

Kolonia Wschodnia

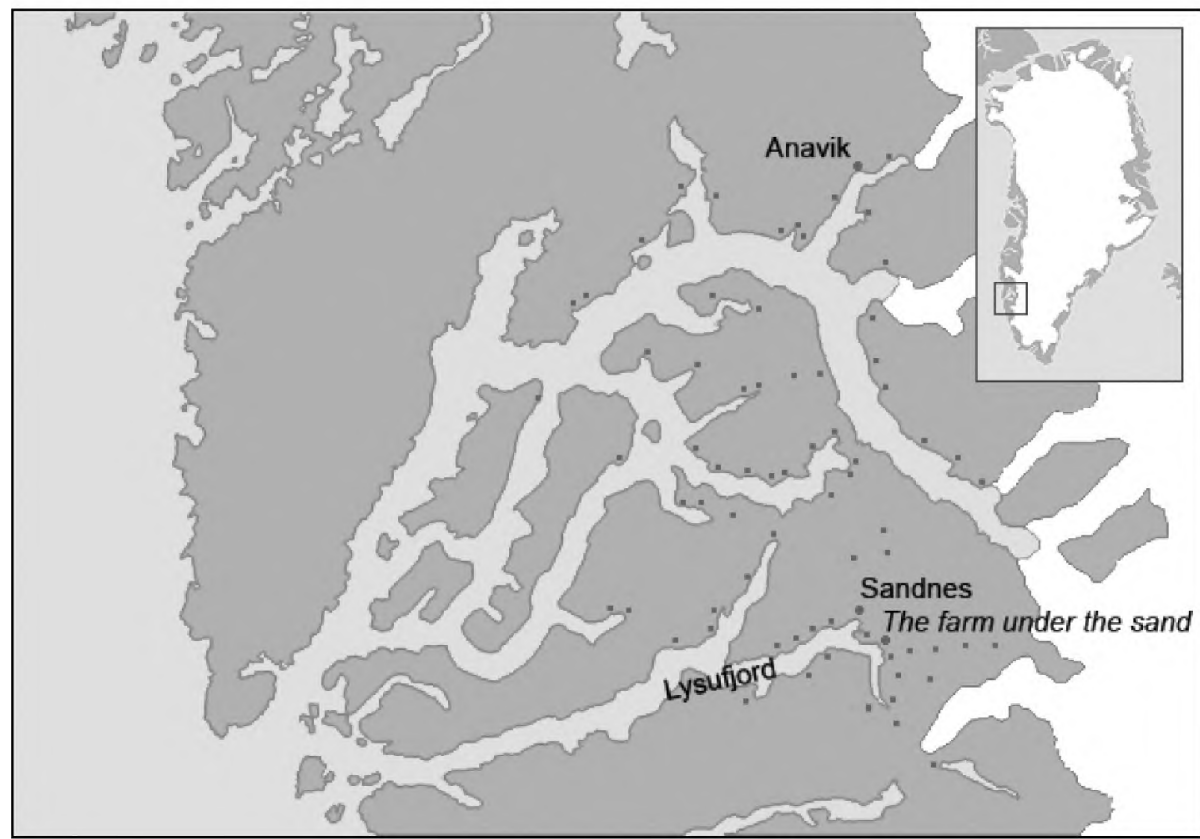

Kolonia Zachodnia 
runku północnym. Bardziej adekwatne byłoby określenie ich jako Kolonia Północna i Południowa. Najnowsze badania wskazują, że w okresie rozkwitu normandzkiego osadnictwa na Grenlandii ich populacja wynosiła ok. 2250 osób. Natomiast na przestrzeni całego okresu zasiedlenia Grenlandii łącznie zamieszkiwało tam ok. 25 tys. Wikingów, ${ }^{11}$ którzy osiedli na 250 farmach zgrupowanych w lokalnych centrach skupionych wokół 14 głównych kościołów. ${ }^{12}$

W przypadku Wikingów znika problem związany z definicją upadku cywilizacji. Ich społeczność nie uległa bowiem jakiejś mniej lub bardziej gruntownej transformacji, kładąc podwaliny pod nową cywilizację. Wikingowie po 500 latach zamieszkiwania na Grenlandii zupełnie wyginęli lub porzucili ten niegościnny ląd, nie pozostawiając po sobie żadnej formy życia społecznego. Nie ma też wątpliwości, co do uznania społeczności Wikingów za cywilizację. Składała się ona bowiem z wystarczająco licznej populacji, miała odpowiednio złożoną strukturę społeczną wraz z panującą elitą, strukturą kościelną i plemienną. Grenlandzcy Wikingowie uznawali zwierzchność króla Norwegii ${ }^{13}$ oraz łączność z papiestwem, czego świadectwem była dziesięcina na rzecz Stolicy Apostolskiej oraz daniny na poczet wypraw krzyżowych. ${ }^{14}$

11 Wcześniejsze badania znacznie wyżej szacowały populację Wikingów. Najwyższe liczby podaje Thomas McGover w swojej pracy doktorskiej The Paleoeconomy of Norse Greenland: Adaptation and Extinction in a Tightly Bounded Ecosystem, New York: Columbia University 1979. Określił on wielkość populacji Wikingów w szczytowym okresie na 5-6 tys. Natomiast łączną liczbę zamieszkujących Grenlandię Wikingów w całym okresie pięćsetletniego osadnictwa ocenił na ok. 70 tys. Analizy przeprowadzone przez Nielsa Lynnerupa wykorzystującego dwie niezależne metody demograficzne (model matematyczny oraz badanie pochówków) doprowadziły go do przekonania, że populacja grenlandzkich Wikingów była znacznie mniejsza niż podawał to McGovern. Wg Lynnerupa przełomowy okres dla ich populacji przypada na rok 1300, a jej wielkość kształtuje się wówczas na poziomie ok. 2250 osób. Uczony ten twierdzi, że od tej pory populacja Wikingów zaczęła stopniowo maleć, by ostatecznie zaniknąć. Współczesne dane statystyczne podają, że na przełomie XX i XXI w. Grenlandię zamieszkuje ok. 60 tys. ludzi. Por. N. Lynnerup, Paleodemography of the Greenland Norse, [w:] "Arctic Anthropology” 1996, Vol. 33, No. 2, s. 131-132, 127.

12 Por. J. Diamond, Collapse. How Societies Choose to Fail or Succeed, Viking Penguin 2005, s. 235. Książka Diamonda została wydana po polsku pt. Upadek. Dlaczego niektóre spoleczeństwa upadty, a innym się udało przez wydawnictwo Prószyński i S-ka w roku 2007. Przypisy w niniejszym opracowaniu odnoszą się do amerykańskiego oryginału. O rozmieszczeniu osad Wikingów pisze także H. Pringle, Death in Norse Greenland, [w:] "Science" Feb 14, 1997, s. 924. 冈rudno jest jednoznacznie określić liczbę farm. Wikipedia pod hasłem History of Greenland podaje, że farm tych było dwukrotnie więcej. Kolonia Wschodnia miała składać się z ok. 500, natomiast Kolonia Zachodnia z 96 farm. Autor opracowania w Wikipedii przeszacował także wielkość populacji, która w myśl badań Nielsa Lynnerupa była ponad dwukrotnie mniejsza. Powodem błędu mogła być liczba farm, którą błędnie zawyżono o tymczasowe schronienia używane jedynie latem.

13 Por. J. Diamond, Collapse, dz. cyt., s. 242-243; por. także 冈. McGovern, The Archaeology of the Norse North Atlantic, art. cyt., s. 342.

14 Por. J. Diamond, Collapse, dz. cyt., s. 244. 


\section{Przyczyny upadku cywilizacji Wikingów na Grenlandii}

Analizując upadek poszczególnych cywilizacji wyróżnia się zwykle różne tego przyczyny. Joseph 囚ainter wskazuje na jedenaście najważniejszych czynników, które prowadzą do upadku: ${ }^{15}$

1. istotne zmniejszenie lub wyczerpanie zasobów, od których uzależniona jest egzystencja cywilizacji;

2. pojawienie się nowych źródeł zasobów;

3. wystąpienie nieprzezwyciężalnych katastrof;

4. niedostateczna odpowiedź na zmieniające się okoliczności życia;

5. inne złożone cywilizacje;

6. intruzi;

7. walka klas, niepokoje społeczne, złe zarządzanie lub złe prowadzenie się elit;

8. dysfunkcja społeczna;

9. czynniki mistyczne;

10. szereg przypadkowych wydarzeń;

11. czynniki ekonomiczne.

Wydaje się, że w przypadku grenlandzkich Wikingów można przyjąć tradycyjny podział przyczyn upadku cywilizacji na przyczyny zewnętrzne, na które Wikingowie nie mieli wplywu oraz przyczyny wewnętrzne, które były bezpośrednim wynikiem ich decyzji.

\section{Przyczyny zewnętrzne}

Do zewnętrznych przyczyn upadku grenlandzkich Wikingów należy ochłodzenie klimatu oraz oddalenie od Europy kontynentalnej. Zmiana klimatu była nieprzewidzianą katastrofą i jednocześnie bezpośrednią przyczyną tego, co Joseph 冈ainter określił jako „zmniejszenie zasobów” niezbędnych dla życia społeczności opartej na gospodarce myśliwsko-hodowlanej. Ponadto fizyczna odległość i utrudniony kontakt $\mathrm{z}$ kontynentem europejskim uniemożliwiały uzupełnienie tych braków.

\section{Ochłodzenie klimatu}

Stopniowe oziębienie klimatu było czynnikiem, który pociągnął za sobą kolejny czynnik - istotne zmniejszenie zasobów żywności. Ochłodzenie spowodowało skrócenie, i tak już bardzo krótkiego okresu wegetacji w siedliskach Wikingów, co ostatecznie doprowadziło do załamania kruchej równowagi, na której balansowali przez ponad pięćset lat. Grenlandzcy Wikingowie nie byli w stanie zabezpieczyć odpowiedniej ilości paszy dla swoich trzód i bez zmiany strategii zdoby-

5 Por. J. A. \aInTER, The Collapse of Complex Societies, dz. cyt., s. 42. 
wania pożywienia tradycyjną formą gospodarki, której podstawą była hodowla, nie mogła zapewnić żywności stosunkowo licznej populacji Wikingów.

Należy zwrócić uwagę na istotną różnicę w warunkach życia pomiędzy obiema koloniami. Różnica ta wynikała $\mathrm{z}$ ich położenia geograficznego. Kolonia Zachodnia $\left(64^{\circ} \mathrm{N}, 52^{\circ} \mathrm{W}\right)$ była wysunięta o ok. $500 \mathrm{~km}$ na północ względem Kolonii Wschodniej $\left(61^{\circ} \mathrm{N}, 46^{\circ} \mathrm{W}\right)$. Bezpośrednim skutkiem różnicy w szerokości geograficznej były istotne różnice temperatur i długość okresu wegetacji. W kolonii bardziej wysuniętej na północ tylko przez 5 miesięcy w roku utrzymywały się temperatury powyżej $0^{\circ} \mathrm{C}$, podczas gdy w Kolonii Wschodniej (położonej bardziej na południe) okres ten wynosił aż 7 miesięcy. ${ }^{16}$ Grenlandia ma chłodniejszy klimat niż Norwegia czy Islandia, które są ogrzewane ciepłym Golfsztromem. Współcześnie klimat na Grenlandii jest podobny do tego, który panował tam w pierwszej fazie osadnictwa Wikingów. 冈emperatury w środku dnia w okresie letnim na terenach dawnych kolonii wynoszą średnio $5-6^{\circ} \mathrm{C}$ (Kolonia Zachodnia) i $10^{\circ} \mathrm{C}$ (Kolonia Wschodniej). Ilość rocznych opadów kształtuje się podobnie w obu koloniach na poziomie $600 \mathrm{~mm} .{ }^{17}$ Obecne badania wskazują, że w latach 800-1300 p.Ch.n. klimat na Grenlandii był relatywnie umiarkowany. Ówczesne warunki klimatyczne były zbliżone do tych, które panują tam dzisiaj. Natomiast na początku XIV wieku klimat zaczął się gwałtownie ochładzać, zaczęło się bowiem tzw. małe zlodowacenie trwające do początku wieku XIX. Ochłodzenie w latach dwudziestych XV wieku było na tyle istotne, że obfitość gór lodowych na wodach otaczających Grenlandię uniemożliwiła żeglugę i odcięla komunikację pomiędzy wyspą a Europą kontynentalną. ${ }^{18}$

Współczesne badania oparte na analizie obecności różnych izotopów niektórych pierwiastków w lodzie pozwalają określić warunki klimatyczne na przestrzeni tysięcy lat. Natomiast na podstawie ilości pyłków roślin znajdujących się na poszczególnych poziomach pokrywy lodowej można określić długość okresu wegetacji i wskazać, które rośliny i w jakiej ilości zdążyły dojrzeć, co z kolei wskazuje na panującą w danym roku temperaturę. Inna metoda badania stanu klimatu polega na analizie zawartości różnych izotopów tlenu w pokrywie lodowej na poszczególnych jej poziomach. Lód był na przestrzeni wieków tworzony z wody, w której znajdują się trzy różne izotopy tlenu, o masie atomowej 16 (stanowi on zwykle 99,8\% całego tlenu), o masie atomowej 18 (ok. 0,2\%) oraz śladowe ilości tlenu o masie atomowej 17. Istnieje prosta prawidłowość polegająca na tym, że

16 Por. J. Diamond, Collapse, dz. cyt., s. 215.

17 Por. \amże, s. 214; por. także G. K. Rutherford, Soils of Some Norse Settlements in Southwestern Greenland, [w:] „Arctic” 1995, Vol. 48, No. 4, s. 324.

18 Por. J. Diamond, Collapse, dz. cyt., s. 219. 
im cieplejsze było lato danego roku, tym większa była zawartość tlenu o masie atomowej $18 \mathrm{w}$ śniegu, $\mathrm{z}$ którego powstawał lód. ${ }^{19}$

Lisa Barlow z Uniwersytetu Kolorado na podstawie analizy składu pokrywy lodowej określiła temperatury poszczególnych lat, począwszy od wczesnego średniowiecza aż do połowy lat osiemdziesiątych XX w. Jej badania wykazały, że w XIV wieku miały miejsce cztery większe okresy niespotykanych ochłodzeń, były to lata: 1308-1318, 1324-1329, 1343-1362 i 1380-1384. Drzeci, najdłuższy okres ochłodzenia niemal pokrywa się z opuszczeniem Kolonii Zachodniej. ${ }^{20}$ Datację tę potwierdzają także radiowęglowe badania kości zwierząt zabitych przez ostatnich mieszkańców kolonii ${ }^{21}$ oraz badania rdzeni lodowych $w$ ramach programu GISP2. ${ }^{22}$ Ekspedycja przybyła do Kolonii Zachodniej ok. roku 1361 nie zastała tam żadnych mieszkańców. Na podstawie napotkanych śladów, Ivar Bardarson - dowódca ekspedycji, nie potrafil ocenić czy mieszkańcy wymarli z powodu głodu lub jakichś chorób, czy też porzucili swoje domostwa. ${ }^{23}$

Podobnie zagadkowe są ostatnie chwile Kolonii Wschodniej. Jette Arneborg - kurator Duńskiego Muzeum Narodowego uważa, że mieszkańców tej osady nie spotkał jakiś kataklizm, lecz została ona opuszczona, o czym świadczy pozostawiony tam porządek. ${ }^{24}$ \rudno jednoznacznie określić datę opuszczenia Kolonii Wschodniej. Niels Lynnerup wskazuje, że ostatnie źródła pisane pochodzące z tej kolonii datowane są na rok 1408. Powszechnie przyjmuje się, że całkowite opuszczenie Kolonii Wschodniej nastąpiło około stu lat później. ${ }^{25}$

Gdy w X wieku Wikingowie osiedlali się na Grenlandii, klimat w regionie północnego Atlantyku był wyjątkowo łagodny. Stworzyło to wystarczające warunki dla kolonizacji tych obszarów. Wydaje się, że ochłodzenie klimatu w wieku XIV i nieprzerwany cykl dwudziestu wyjątkowo srogich zim oraz chłodnych okresów letnich były bezpośrednimi przyczynami opuszczenia Kolonii Zachodniej. ${ }^{26}$ Osadnictwo Wikingów w Kolonii Wschodniej przetrwało znacznie

19 Por. 冈amże, s. 217-218; por także P. C. Buckland, 囚. Amorosi, L. K. Barlow, A. J. Dugmore, P. A. Mayewski, 囚. H. McGovern, A. E. J. Oglivie, J. P. SAdler, P. Skidmore, Bioarchaeological and climatological evidence for the fate of Norse farmers in medieval Greenland, [w:] "Antiquity" 1966, Vol. 70, s. 88, 94.

20 Por. N. Lynnerup, Paleodemography of the Greenland Norse, art. cyt., s. 122.

21 Por. H. Pringle, Death in Norse Greenland, art. cyt., s. 925.

22 GISP2 to program zainicjowany pod koniec roku 1988 przez amerykański Office of Polar Programs. GISP2 jest skrótem od Greenland Ice Sheet Project 2. W ramach tego program dokonano niezwykle cennych odkryć. Wwiercono się w pokrywę lodową na głębokość 3053,44 $\mathrm{m}$. Otworzyło to nową erę $\mathrm{w}$ badaniach paleośrodowiskowych na terenach arktycznych. Por. Welcome to GISP2, <http://www.gisp2.sr.unh.edu/> (Data dostępu 21.06.2008); por. także P. C. Buckland et al., Bioarchaeological and climatological evidence..., art. cyt., s. 88-96.

23 Por. H. Pringle, Death in Norse Greenland, art. cyt., s. 924.

24 Por. \amże, s. 925.

25 Por. N. Lynnerup, Paleodemography of the Greenland Norse, art. cyt., s. 122.

26 Por. H. Pringle, Death in Norse Greenland, art. cyt., s. 925. 
dłużej. Stopniowe ochładzanie się klimatu nie dawało jednak szans na przetrwanie społeczności, której ekonomia była oparta na rolnictwie i hodowli.

\section{Oddalenie od kontynentu i brak komunikacji z Europą}

Kolejnym istotnym czynnikiem, który wpłynął na zagładę grenlandzkich Wikingów było oddalenie od kontynentu oraz rzadki i ryzykowny kontakt handlowy między grenlandzkimi osadami i Europą. Đrudno ten czynnik utożsamić z którąś z przyczyn upadku cywilizacji wymienionych przez Josepha Đaintera. Wydaje się jednak, że był on ważny, jakkolwiek nie pierwszorzędny. Możliwość częstszych kontaktów dałaby okazję do uzupełnienia brakujących zasobów, wymianę myśli oraz otwarcie się na odmienność. Podróż statkiem z Norwegii na Grenlandię trwała wówczas ponad tydzień i była obarczona wielkim ryzykiem. \ak więc zwykle do Grenlandii zawijało rocznie nie więcej, niż dwa okręty. Zdarzało się, że do grenlandzkich brzegów przybijał tylko jeden statek na przestrzeni kilku lat. Możliwości transportowe ówczesnych okrętów były niewielkie. Przy dwóch statkach rocznie, cargo wynosiło średnio ok. 3,5 kg towarów na jednego mieszkańca Grenlandii. Średnio, bo tylko nieliczni Wikingowie otrzymywali cokolwiek spośród importowanych towarów, których większość była przeznaczona na luksusy dla elity i potrzeby kultu. Grenlandia musiała być więc pod wieloma względami samowystarczalna. Do najpotrzebniejszych towarów sprowadzanych na Grenlandię należały: żelazo (niemożność wytwarzania, brak dobrej rudy i paliwa do wytopu), drewno na budulec i meble oraz smoła i smar, których używano jako konserwantów do drewna.

Wspomniane czynniki klimatyczne oraz geograficzne oddalenie od Europy są istotne, lecz dla potrzeb niniejszego opracowania mało interesujące. $\mathrm{O}$ wiele ważniejsze są te przyczyny upadku normandzkiego osadnictwa na Grenlandii, na które mieli oni wpływ. Prowokują one bowiem pytania o to, dlaczego Wikingowie nie zareagowali właściwie na zachodzące zmiany i pozwolili, by los ich cywilizacji zakończył się tragiczne.

\section{Przyczyny wewnętrzne}

Do wewnętrznych przyczyn upadku cywilizacji grenlandzkich Wikingów należy zaliczyć niedostateczną odpowiedź na zmieniające się warunki życia; czynniki ekonomiczne oraz czynniki mistyczne. Wszystkie te elementy znajdują się wśród przyczyn upadku cywilizacji wymienionych przez \aintera. Wydaje się, że poszczególne przyczyny wzajemnie się warunkują i istnieje pewna wewnętrzna dynamika ich interakcji. 囚ym co je łączy jest fakt, że przyczyny te były uwarunkowane decyzjami człowieka. Inne strategie grenlandzkich elit mogły znacznie przedłużyć obecność Wikingów na Grenlandii lub nawet zapewnić ich przetrwanie do naszych czasów. 


\section{Niedostateczna odpowiedź na zmieniające się warunki życia}

Dla zrozumienia stylu życia grenlandzkich Wikingów przyjrzymy się ich rocznemu kalendarzowi aktywności. Wraz z nastaniem wiosny (późny maj lub wczesny czerwiec) miał miejsce kluczowy okres dla ekonomii grenlandzkich osad. Wtedy to właśnie migrujące foki siodlaste (Pagophilus groenlandicus) i foki kapturowe (Cystophora cristata) łączą się w stada u wybrzeży Grenlandii i wraz z miejscową foką pospolitą (Phoca vitulina) wychodzą na plaże Grenlandii, by wydać na świat potomstwo. Był to okres, kiedy można było najłatwiej upolować foki gromadzące się w wielkich stadach. Miesiące letnie (od czerwca do sierpnia) były okresem szczególnie wytężonej pracy, kiedy to wypędzano trzody na pastwiska. Bydło w obfitości dostarczało wówczas mleka, które należało przetworzyć na masło i sery, które z kolei stanowiły ważny składnik diety w okresie zimy. Część mężczyzn w tym okresie wyprawiała się na Labrador w celu pozyskania drewna na budulec. Inne łodzie wyruszały daleko na północ, by polować na niedźwiedzie i sokoły polarne oraz morsy. W tym też czasie przypływały (o ile przypływały w ogóle) statki handlowe z Islandii lub Europy przywożąc towary niedostępne na Grenlandii. ${ }^{27}$

Sierpień i wrzesień były gorączkowym okresem sianokosów i zabezpieczania paszy dla trzody na zimę. W końcu sierpnia zwierzęta zapędzano ponownie do obór lub bliżej domostw. W tym samym okresie zaczynał się okres polowań na karibu. Następne miesiące (od października do kwietnia) to czas doglądania zwierząt $w$ oborach, tkania i naprawiania odzieży oraz remonty domostw, a także obrabiania kłów morsów upolowanych latem. Okres mroźnej zimy był także czasem gorącej modlitwy, by zebrana żywność dla ludzi i pasza dla zwierząt oraz zgromadzone zapasy opału nie skończyły się przed końcem srogiej zimy. Wydaje się, że żadna $z$ osad nie była samowystarczalna. Konieczna była wzajemna wymiana. O ile osady bardziej wysunięte na południe obfitowały w lepsze pastwiska, o tyle osady północne dysponowały zasobniejszymi terenami myśliwskimi. Wikingowie wymieniali się więc swoimi zasobami uzupełniając w ten sposób lokalne braki. Świadczą o tym wykopaliska, w ramach których na farmach znacznie oddalonych od wody znajduje się liczne kości fok, a kości bydła występują w osadach, gdzie hodowla była niemożliwa. ${ }^{28}$

Widać więc wyraźnie, że ekonomia Wikingów była oparta na połączeniu hodowli oraz myślistwa. Gospodarka grenlandzkich Wikingów była o wiele bardziej uzależniona od polowań na dzikie zwierzęta, niż było to w przypadku Wikingów zamieszkujących Islandię czy Norwegię, gdzie znacznie więcej żywności uzyskiwano $\mathrm{z}$ hodowli trzód. Istnieją dowody na to, że próbowano wprowadzić na

27 Por. J. Diamond, Collapse, dz. cyt., s. 231.

28 Por. 囚amże, s. 231-232. 
Grenlandii zwyczaje hodowlane przywiezione z Norwegii, jak np. hodowlę świń. Lekkie gleby tamtejszego obszaru były jednak szczególnie wrażliwe na dewastacje, jakich dopuszczały się te zwierzęta powodując nieodwracalne straty w tamtejszym środowisku naturalnym. W krótkim więc czasie znacznie zmniejszono populację tych zwierząt. Badania wykopaliskowe wskazują też na obecność nielicznych koni, które były używane jako zwierzęta pociągowe. W grenlandzkim klimacie bydło wymagało znacznie większego nakładu pracy i troski niż owce czy kozy. Bydło mogło bowiem samodzielnie znaleźć paszę jedynie przez 3 miesiące w roku. O wiele lepiej sprawdzały się owce i kozy, które były w stanie samodzielnie wygrzebać paszę spod zmarzniętego śniegu i były bardziej odporne na warunki atmosferyczne. Posiadanie krów było jednak oznaką prestiżu i pozycji społecznej, dlatego wbrew przesłankom ekonomicznym, forsowano hodowlę bydła. Wraz ze zmianami klimatycznymi stosunek ilości zwierząt poszczególnych gatunków stopniowo się zmieniał na korzyść kóz. ${ }^{29}$

Dane archeologiczne wskazują, że dieta mieszkańców bardzo ubogiej osady Niaquusat oznaczanej symbolem W48 w Kolonii Zachodniej składała się z mięsa fok (85\%), mięsa kóz (6\%), mięsa karibu (5\%), mięsa owiec (3\%), i tylko w $1 \%$ $\mathrm{z}$ wołowiny. W tym samym czasie w Sandnes - najbogatszej farmie należącej do Kolonii Zachodniej, dieta jej mieszkańców składała się w 32\% z mięsa karibu, $17 \%$ z wołowiny, $6 \%$ mięsa owiec, $6 \%$ mięsa kóz oraz z w tylko $39 \%$ z mięsa fok. Najlepsze warunki żywieniowe miała elita Kolonii Wschodniej, gdzie na farmie Eryka Rudego w Brattahlid (dzisiejszy Qassiarsuk) spożycie wołowiny przewyższało w znacznym stopniu spożycie zarówno mięsa karibu, jak i owiec a nawet kóz. ${ }^{30}$

Pod posadzką katedry św. Mikołaja w Gardarze (dzisiejszy Igaliku) znaleziono szkielet mężczyzny w stroju biskupa ${ }^{31}$ który poddano skrupulatnym badaniom. W ich wyniku udało się ustalić, że dieta tego notabla składała się w $75 \%$ z pokarmów pochodzenia lądowego (w większości wołowiny i sera) i tylko $25 \%$ z pokarmów pochodzenia morskiego (w większości fok). Współcześni biskupowi członkowie elity spożywali nieco mniej atrakcyjne pokarmy. Ich dieta w $45 \%$

29 Por. 冈amże, s. 222-223. Współczesne badania porównawcze na temat wymagań krów i owiec na terenie Kolonii Wschodniej wskazują, że wpływ na środowisko jednej dorosłej krowy był mniej więcej taki sam jak dziesięciu dorosłych owiec. Szacuje się też, że stosunek ilości krów do ilości kóz na farmie Sandnes (Kolonia Zachodnia), oznaczanej jako V35, był jak 1 do 4,5. Przy liczebności krów wynoszącej 4, kóz było 18. Por. \. H. McGovern, G.F. Biegelow, 囚. Amorosi, D. Russell, Northern Islands, Human Error, and Environmental Degradation, [w:] D. G. Bates (red.), S. H. Lees (red.), Case Studies in Human Ecology, New York - London: Plenum Press 1996, s. 116, 118.

30 Por. J. Diamond, Collapse, dz. cyt., s. 233.

31 Najprawdopodobniej były to doczesne szczątki Johna Arnasona Smyrilla, biskupa Grenlandii w latach 1189-1209, por. 凶amże, s. 234. 
składała się z produktów morskich. Zawartość pokarmów pochodzenia morskiego w pożywieniu Wikingów była uzależniona od ich statusu społecznego i lokalizacji osady. W szczątkach osób niskiego stanu zamieszkujących Kolonię Wschodnią znaleziono ślady $78 \%$ żywności morskiej, natomiast u mieszkańców Kolonii Zachodniej nawet $81 \% .^{32}$ Przyczyną takiego stanu rzeczy były czynniki klimatyczne. W farmach należących do Kolonii Wschodniej produkowano bowiem trzykrotnie więcej paszy dla zwierząt niż w farmach należących do Kolonii Zachodniej. ${ }^{33}$ Dzięki takim warunkom oraz względom politycznym i prestiżowym w Gandarze znajdowała się obora mogąca pomieścić 160 krów. Hodowano tam bydło w ilościach nie przystających do wydolności okolicznych pastwisk. ${ }^{34}$

Na podstawie przytoczonych danych widać wyraźnie, że ekonomia grenlandzkich Wikingów była sterowana ideologicznie. Przywiezione zwyczaje i upodobania do hodowli nie odpowiadały lokalnym możliwościom i były sprzeczne z rachunkiem ekonomicznym. Zmiana zwyczajów żywieniowych i strategii gospodarczych mogła odłożyć w czasie upadek ich cywilizacji lub nawet zupełnie mu zaradzić.

Jeszcze bardziej tajemnicza jest nieobecność ryb na stołach grenlandzkich Wikingów. Badania archeologiczne prowadzone na terenie różnych osad potwierdzają, że grenlandzcy Normanowie niemal wcale nie jedli ryb, chociaż przywędrowali z Norwegii i Islandii, gdzie rybołówstwo było znane i powszechnie praktykowane. Wśród różnych szczątków zwierzęcych znalezionych w grenlandzkich osadach mniej niż $0,1 \%$ wszystkich kości stanowią szczątki ryb. W podobnych osadach Wikingów na Islandii, Szetlandach i w północnej Norwegii odsetek znalezionych szczątków rybnych waha się od 50\% do 95\%. I tak np. podczas wykopalisk prowadzonych przez Thomasa McGoverna wśród wszystkich szczątków w osadzie Vatnahverfi znaleziono jedynie trzy rybie szkielety. Podczas gdy wśród wykopalisk prowadzonych przez Georga Nygaarda na ogólną ilość kości wynoszącą 35 tys., znaleziono szczątki tylko dwóch ryb. Na stanowisku wykopaliskowym oznaczonym Ö34, gdzie znaleziono wyjątkowo dużo, bo aż 166 rybich szczątków, stanowiły one zaledwie 0,7\% ogólnej ilości kości zwierzęcych. Sytuacja jest tym dziwniejsza, gdy weźmiemy pod uwagę nieustanne braki pokarmu, z jakimi borykali się grenlandzcy Wikingowie oraz obfitość i dostępność ryb. Wśród najliczniej występujących wówczas ryb morskich był plamiak (Melanogrammus aeglefinus - duża ryba osiągająca wagę nawet do $12 \mathrm{~kg}$ ) oraz dorsz. Grenlandia obfituje także w ryby słodkowodne, szczególnie pstrągi, które dziś można tam łapać gołymi rękami. Prawdopodobnie dostępność tych gatunków w okresie osadnictwa Wikingów była podobna do dzisiejszej. Nawet, jeśli Wikingowie nie

\footnotetext{
Por. \amże, s. 233-234.

33 Por. 冈amże, s. 232.

34 Por 囚amże, s. 235.
} 
chcieli sami spożywać ryb, mogły one służyć za pokarm dla psów i zaoszczędzić w ten sposób trochę mięsa fok dla potrzeb ludzi. Nie ma jednak śladów takich praktyk. Jared Diamond zwraca uwagę, że bardzo wielu archeologów uczestniczących w badaniach terenowych na terenie Grenlandii jest kompletnie zaskoczonych faktem, że grenlandzcy Wikingowie w ogóle nie jadali ryb. ${ }^{35}$

O ile Joseph 凶ainter wśród przyczyn upadku niektórych cywilizacji wylicza pojawienie się zupełnie nowych zasobów, o tyle w przypadku Grenlandii można przypuszczać, że przyczyną ich upadku była niechęć do skorzystania z łatwo dostępnych zasobów żywności. Pojawia się pytanie o powody tej niechęci. Wszystko wskazuje na to, że miała ona podłoże kulturowe i nie tylko nie skłaniała ich do spożywania ryb, ale wręcz od tego odwodziła. Diamond próbując wytłumaczyć taki stan rzeczy, stawia hipotezę, że pomimo tego, iż grenlandzcy Wikingowie wywodzili się z kultury, w której ryby stanowiły istotny element pożywienia, to prawdopodobnie wprowadzili swego rodzaju żywieniowe tabu zabraniające spożywania ryb. Wikingowie, podobnie jak każda społeczność, mieli tabu polegające na niespożywaniu niektórych pokarmów, by podkreślić swoją odmienność od innych społeczności - „my szlachetni i czyści nie jemy tych rzeczy, którymi członkowie obcych i obrzydliwych społeczności się delektują". Znaczna część tabu żywieniowych dotyczy mięsa i ryb. W kręgu kultury francuskiej jada się np. żaby, ślimaki i konie. Nowogwinejczycy chętnie spożywają szczury, pająki i larwy chrząszczy, a Polinezyjczycy jedzą morskie larwy. Wszystkie te pokarmy zawierają wiele cennych substancji odżywczych. Większość przedstawicieli kultury euroatlantyckiej nie weźmie ich jednak do ust. Wydaje się, że powodem, dla którego na mięso i ryby częściej, niż na pokarmy roślinne, nakładane jest tabu jest fakt, że w mięsie i rybach szybciej i łatwiej rozwijają się bakterie i pasożyty, co jest przyczyną niebezpiecznych zatruć. Jared Diamond przypuszcza, że właśnie taka sytuacja musiała mieć miejsce podczas pierwszych lat pobytu Eryka Rudego na Grenlandii. Prawdopodobnie znaczna część ówczesnej społeczności musiała się zatruć rybami, co w konsekwencji sprowokowało niechęć do jedzenia ryb oraz kulturowe jej umotywowanie i utrwalenie. W opinii Diamonda motywowano to tak: „my Wikingowie jesteśmy szlachetnymi i dumnymi ludźmi, którzy nie będą

\footnotetext{
Por. \amże, s. 229. Brak ryb w jadłospisie grenlandzkich Wikingów oraz obfitość ryb na stole ich kuzynów zamieszkujących tereny poza Grenlandią potwierdzają także badania porównawcze przeprowadzone na dwóch podobnych, co do wielkości i funkcji farmach. Analiza badań przeprowadzonych na stanowisku (SVB) nieopodal farmy Svalbar na jednej z wysp oraz na stanowisku (V51) nieopodal farmy Sandnes wskazuje, że obie farmy byly zamieszkane w tych samych latach 1000-1050 przez podobną ilość osób. Szczątki zwierząt odkrytych na tych stanowiskach potwierdzają, że grenlandzcy Wikingowie prawie nie spożywali ryb, natomiast namiętnie polowali na morsy. Podczas gdy ich kuzyni z odległej wyspy spożywali mnóstwo ryb, a w niebezpiecznych polowaniach na morsy uczestniczyli bardzo rzadko. Por. P. C. BuckLand et al., Bioarchaeological and climatological evidence..., art. cyt., s. 91.
} 
spożywali tego typu żywności. My jesteśmy inni od tych brudnych Islandczyków i norweskich rybożerców."36

\section{Niezapożyczenie nowych technik łowieckich i technologii}

Kolejnym ważnym czynnikiem klęski Wikingów był brak przystosowania się do nowych technik łowieckich. Nie przyjęcie od Inuitów technik łowieckich i zwyczajów żywieniowych stanowiło dla Wikingów bezpowrotnie zaprzepaszczoną szansę. Gdyby Wikingowie nawiązali z nimi dobrosąsiedzkie relacje lub przynajmniej wymianę handlową, ich szanse na przetrwanie znacznie by wzrosty. Nie wiadomo co ostatecznie stało się przyczyną upadku kolonii Wikingów. Nie ma też dowodów świadczących, że ich upadek był wynikiem wojny z Inuitami. Faktem jest jednak, że Inuici znacznie dłużej niż Wikingowie przebywali w klimacie arktycznym i wypracowali dużo skutecznych strategii przystosowawczych do życia w tych warunkach. Inuici przybyli na Grenlandię z terenów północnej Kanady. Warunki więc, z których przychodzili były zbliżone do tych, które zastali na Grenlandii. Punkt startu Inuitów i Wikingów był więc inny. ${ }^{37}$

Inuici stosowali zupełnie inne techniki myśliwskie i podróżnicze. Jeszcze przed rokiem tysięcznym p.Ch.n. opanowali technikę polowań na wieloryby na otwartym morzu przy użyciu skórzanych łodzi. Stosowali sanie ciągnięte przez psie zaprzęgi oraz duże łodzie do transportu i przemieszczania się. Inuici używali podczas polowań łuków i strzał. ${ }^{38}$ Dzięki polowaniom na wieloryby mieli obfite źródło pożywienia, które było zupełnie niedostępne dla Wikingów, a poprzez to mogli tworzyć większe osady złożone z kilkudziesięciu osób, w tym 10-20 myśliwych i wojowników. Inuici, jako dłużej obecni w klimacie arktycznym, wykształcili też skuteczniejsze strategie budowy schronień. $Z$ powodu niedoboru drewna na opał i budulec, wypracowali technikę budowy igloo, a do oświetlenia i ogrzewania używali foczego i wielorybiego tłuszczu. Nie potrzebowali też dużych ilości drewna na budulec, ponieważ łodzie obciągali skórami fok. Używali harpunów połączonych liną z napełnionymi powietrzem workami ze skóry. Miało to na celu spowalniać ucieczkę trafionych zwierząt i zabezpieczać łup oraz cenne ostrze przed utonięciem. ${ }^{39}$

Dzięki tym technikom myśliwskim, Inuici są uznawani za najbardziej wyrafinowanych myśliwych w historii Arktyki. Oprócz polowań na karibu, morsy i ptaki (na które Wikingowie także polowali) Inuici polowali ponadto (dzięki

\footnotetext{
36 J. Diamond, Collapse, dz. cyt., s. 230. Prawdopodobnie do grona „innych” Wikingowie włączali Inuitów, z którymi mieli sporadyczne kontakty.

37 Por. J. Diamond, Collapse, dz. cyt., s. 255; por. także R. McGheE, Inuit and Norsemen in Arctic Canada A.D. 1000 to 1400, <http://www.civilization.ca/cmc/archeo/oracles/norse/40.htm > (Data dostępu: 21.06.2008).

38 Por. J. Diamond, Collapse, dz. cyt., s. 257.

39 Por. 囚amże, s. 258.
} 
skórzanym kajakom) na foki i ptaki oraz wieloryby, czego absolutnie nie potrafili Wikingowie. Inuici stosowali także zupełnie niespotykaną wśród Wikingów technikę polowań na foki obrączkowane (Phoca hispida), które występowały na wodach Grenlandii w wielkiej liczbie. Zwyczaje tych fok powodowały, ze były one bardzo trudnym łupem dla myśliwych. Foki obrączkowane w okresie zimy wytapiały ciepłem swojego ciała kanały lodowe prowadzące do powierzchni i pozwalające im zaczerpnąć powietrza. Dla bezpieczeństwa każda foka posiadała kilka takich otworów oddechowych. Stanowiło to znaczne wyzwanie dla myśliwego, który w ciemnościach arktycznej zimy czekał cierpliwie, aż foka podpłynie do danego otworu, by mógł jej zadać śmiertelny cios. Wymagało to od myśliwego ogromnej cierpliwości i odporności na wychłodzenie organizmu, ponieważ musiał on zachowywać niemal idealną ciszę i bezruch. Wikingowie nigdy nie zapożyczyli tej techniki, zresztą nie mieli żelaza, by móc sporządzić odpowiednie harpuny. ${ }^{40}$

Pomimo tego, że Wikingowie i Inuici przez kilka stuleci przebywali na tych samych obszarach, w kronikach Wikingów odnotowujemy tylko 3 małe wzmianki o kontakcie z Inuitami. Wzmianki te odnoszą się do incydentalnych kontaktów między obiema stronami. Ich autorzy wskazują, że kontakty te miały charakter wrogi i burzliwy, a zależnie od okoliczności, kończyły się śmiercią jednych lub drugich. Wpisuje się to w obraz, który znamy z innych podań na temat temperamentu i porywczości Wikingów. Świadectwa te tłumaczą dlaczego w przeciągu kilku stuleci nie potrafili oni nawiązać sąsiedzkich relacji z Inuitami i zapożyczyć od nich technik myśliwskich i metod przystosowania się do arktycznego środowiska. ${ }^{41}$

Jedynym pewnym świadectwem o bezpośrednich kontaktach Inuitów z Wikingami są inuickie rzeźby przedstawiające postacie ludzkie ubrane w charakterystyczne stroje Wikingów. ${ }^{42}$ Najprawdopodobniej to Inuici zapożyczyli od Wikingów pewne technologie, których sami wcześniej nie znali. Chodzi tu szczególnie o kształt, jaki nadali swoim nożom (mogli je skopiować od Wikingów bez udziału tych ostatnich). Inuici nauczyli się także produkcji beczek z drewnianych klepek oraz wkręcanych do strzał grotów. Sugeruje to, że musieli widzieć ich wy-

40 Por. \amże, s. 260.

${ }^{41}$ Por. \amże, s. 261-262; por. także P. C. BuckLAND et al., Bioarchaeological and climatological evidence..., art. cyt., s. 94.

42 Oryginał drewnianej rzeźby znalezionej w XIII wiecznym siedzibie Inuitów na Wyspie Baffina znajduje się National Museums of Canada. Drugim ważnym artefaktem świadczącym o tym, że Inuici w jakiśs sposób pozyskali przedmioty pochodzące od Wikingów, jest fragment wagi z brązu używanej przez Wikingów. Fragment ten, który odnaleziono w osadzie Inuitów na zachodnim brzegu Wyspy Ellesmere’a, także znajduje się w zbiorach National Museums of Canada. Por. R. MCGHEE, Inuit and Norsemen in Arctic Canada A.D. 1000 to 1400, <http://www.civilization. $\mathrm{ca} / \mathrm{cmc} /$ archeo/oracles/norse $/ 40 . \mathrm{htm}>$ (Data dostępu: 21.06.2008). 
konujących te przedmioty. Natomiast u Wikingów nie dostrzegamy niemal żadnych przedmiotów, które mogłyby należeć do Inuitów. ${ }^{43}$

Na stanowiskach archeologicznych badających osady Wikingów nie znaleziono nawet najmniejszych śladów harpunów, miotaczy harpunów ani skórzanych łodzi Inuitów. Wskazuje to, że najprawdopodobniej nie było żadnych kontaktów handlowych pomiędzy tymi ludami. Nie ma też żadnych śladów antropologicznych czy genetycznych świadczących o mieszanych małżeństwach. ${ }^{44}$

\section{Czynniki ekonomiczne}

Wikingowie identyfikowali się wyraźnie z kulturą europejską i kontakty z kontynentem byly dla nich niezmiernie ważne, zarówno pod względem kulturowym, jak i ekonomicznym. Handel z Europą wymagał od Wikingów przedstawienia atrakcyjnej oferty w postaci rzadkich lub zupełnie niedostępnych towarów dla mieszkańców kontynentalnej Europy. Stanowiły one zapłatę za przywożone na Grenlandię towary i jednocześnie skłaniały kapitanów statków do podejmowania ryzykownych wypraw do grenlandzkich portów. \akimi dobrami były zwierzęta polarne oraz produkowana przez Wikingów wełniana odzież. Wprawdzie Zachodnia Kolonia była znacznie mniejsza ${ }^{45}$ i miała gorsze warunki hodowlane, posiadała jednak wielkie znaczenie dla ich ekonomii ze względu na znacznie łatwiejszy dostęp do północnych terenów myśliwskich. Łowiska te obfitowały w zwierzęta, których skóry i trofea mogły być przedmiotem wymiany handlowej z przybywającymi na Grenlandię statkami. ${ }^{46}$

W połowie XIII wieku bywały okresy, gdy przez wiele lat z rzędu do Grenlandii nie zawinął żaden statek. W roku 1257 król Norwegii Haakon Haakonsson wysłał trzech komisarzy w celu potwierdzenia swojego zwierzchnictwa nad Grenlandią. Wydaje się, że dopiero w 1261 prawa króla zostały uznane przez Wikingów w zamian za obietnicę króla, że 2 statki rocznie będą przybijać do brzegów Grenlandii. ${ }^{47}$

43 Podczas wszystkich dotychczasowych wykopalisk prowadzonych w siedliskach Wikingów znaleziono jedynie 5 przedmiotów, które mogłyby należeć do Inuitów. Por. J. Diamond, Collapse, dz. cyt., s. 262-263.

44 Por. \amże, s. 263.

45 Wielkość Kolonii Zachodniej określa się zwykle jako 1/3 Kolonii Wschodniej. Prawdopodobnie tworzyło ją 25 farm rozrzuconych na dość dużym obszarze i oddalonych od siebie $3-5 \mathrm{~km}$. Por. 囚. H. McGovern, G.F. Biegelow, 囚. Amorosi, D. Russell, Northern Islands, Human Error, and Environmental Degradation, art. cyt., s. 115.

46 Por. J. Diamond, Collapse, dz. cyt., s. 232.

47 Por. \amże, s. 243; por. także N. LynNerup, Paleodemography of the Greenland Norse, art. cyt., s. 122. 
Podróż statkiem z Norwegii do Grenlandii trwała nieco ponad tydzień i była bardzo niebezpieczna ze względu na zmienną i kapryśną pogodę, słabo rozpoznane wody oraz obecność gór lodowych. $Z$ tych względów przybywało tam rocznie nie więcej niż 2 jednostki, a czasami tylko jeden statek na kilka lat. Nośność ówczesnych okrętów była niewielka. Przy dwóch statkach przybijających do wybrzeży Grenlandii w roku, średnie roczne cargo w przeliczeniu na jednego mieszkańca wynosiło ok. $3 \mathrm{~kg}$. Średnio, bo większość grenlandzkich Wikingów otrzymywała bardzo niewiele. Większość towarów z Europy to przedmioty luksusowe na użytek elit lub sprzęty potrzebne do sprawowania kultu. Grenlandia musiała być więc samowystarczalna pod względem żywnościowym. Najpotrzebniejsze rzeczy, których nie byli w stanie uzyskać na swojej wyspie to: żelazo (brak dobrej rudy i paliwa do wytopu), drewno na budulec i meble oraz smoła i smar jako konserwant do drewna. Wiele spośród tych produktów było sprowadzanych w bardzo niewielkich ilościach z powodu ograniczonych możliwości finansowych oraz dużych nakładów na towary ekskluzywne dla elit. ${ }^{48}$

W zamian za kupowane produkty Wikingowie dostarczali swoim europejskim kontrahentom: skóry kóz, krów i fok oraz wełniane ubrania, które były odporne na przemakanie, a ponadto bardzo cenione w Europie zwierzęta polarne. ${ }^{49}$ Wikingowie musieli wyprawiać się więc na polowanie kilkaset mil na północ od Kolonii Zachodniej w celu zdobycia produktów na wymianę. Posługiwali się przy tym sześcioosobowymi otwartymi łodziami wiosłowymi z żaglem, które mogły pokonać dziennie ok. 20 mil i były w stanie wziąć na pokład do 1,5 tony ładunku. Myśliwi odpływali więc w czerwcu w szczycie połowu fok i zajmowało im ok. 2 tygodni dotarcie na miejsce $\mathrm{z}$ Kolonii Zachodniej, lub 4 tygodnie $\mathrm{z}$ Kolonii Wschodniej. Wracali do swoich osad dopiero pod koniec sierpnia. W tych łodziach nie byli w stanie przywieźć mięsa upolowanych zwierząt, a jedynie ich trofea na sprzedaż oraz ewentualnie żywe niedźwiadki polarne lub sokoły. ${ }^{50}$

Żeby poznać ekonomię Wikingów, Thomas McGovern spędził niemal 20 lat na badaniach terenowych analizując kości zwierząt znalezione w rozsia-

48 Przykładem mogą tu być np. dzwony kościelne, witraże, świeczniki z brązu, wino mszalne, len, jedwab, srebro, szaty kościelne i biżuteria. Do przedmiotów luksusowych znalezionych na Grenlandii należą m.in.: naczynia cynowe, ceramika, szklane paciorki i guziki oraz niewielkie ilości luksusowej żywności: miód i sól.

49 Do najczęściej eksportowanych produktów należaly: kly i skóry morsów (szczególnie cenione z powodu wytrzymałości do produkcji lin okrętowych), żywe niedźwiedzie polarne oraz ich skóry, które były w Europie oznaką władzy i symbolem wysokiego statusu społecznego. Bardzo cenione były także żywe sokoły polarne (największy gatunek sokoła). Kły morsów zastępowały w Europie kość słoniową, po tym jak muzulmanie przejęli kontrolę nad Morzem Śródziemnym i zablokowali handel z Indiami i Afryką. O wartości sokołów świadczy fakt, że w roku 1396 za 12 tych ptaków został wykupiony z niewoli syn księcia Burgundii.

50 Por. J. Diamond, Collapse, dz. cyt., s. 240-241. 
nych po Grenlandii normandzkich osadach. Na podstawie tych badań określił wielkość i gatunki hodowanych zwierząt a nawet dietę Wikingów. Porównał ogromny materiał zebrany w tym okresie $z$ historycznymi sagami o życiu tego ludu. Potwierdził wcześniejsze przypuszczenia o wyprawach myśliwskich na północ $w$ celu zdobycia kłów morsów i skór na wymianę towarową z kupcami. ${ }^{51}$ Potwierdził także fakt, że Wikingowie zajmowali się hodowlą owiec, kóz i bydła oraz polowali na karibu i foki. Długotrwałe badania doprowadziły McGoverna do przekonania, że mieszkańcy obu kolonii prawie w ogóle nie spożywali ryb. Potwierdzają to także badania Buklanda, który tak charakteryzuje kulturę tego ludu: „刃ak więc była to nie-morska kultura na brzegu morza". ${ }^{2}$

Polowania pociągały ze sobą wielkie ryzyko, często zdarzały się bowiem wypadki śmierci poszczególnych myśliwych lub całych ich grup. Niebagatelną sprawą było opuszczenie osad przez najbardziej sprawnych mężczyzn w czasie, gdy na farmach było najwięcej pracy. Często od letniej pracy na farmie uzależnione było przetrwanie osady w okresie zimy. Ponadto zwierzęta i ich trofea okupione tak wielkim wysiłkiem były inwestowane w przedmioty, które w żaden sposób nie przyczyniały się do polepszenia jakości życia przeciętnych mieszkańców. Nie oddalały też nadchodzącego widma zagłady.

Wikingowie nie mieli więc środków na zakup narzędzi metalowych, które by ułatwiły i usprawniły sianokosy i polowania. W miejsce narzędzi metalowych byli zmuszeni używać narzędzi sporządzonych z kości i kamienia. Praca przy ich użyciu wymagała większego nakładu sił, a przede wszystkim czasu, którego w okresie krótkiego lata najbardziej brakowało. ${ }^{53}$

Na zmiany związane $\mathrm{z}$ ochłodzeniem klimatu nakładała się także nierozsądna gospodarka. Po przybyciu na Grenlandię, Wikingowie wypalili bowiem lasy na pastwiska, co z kolei spowodowało erozję gleby poprzez silne wiatry obecne w tamtejszym klimacie. Wyeksploatowali także zasoby torfu na opał. Świnie hodowane $w$ pierwszej fazie osadnictwa także znacząco wpłynęły na erozję gleby. ${ }^{54}$ Ważnym czynnikiem mającym wpływ na ekonomię grenlandzkich Wikingów były wydatki związane z utrzymaniem świątyń i hierarchii kościelnej. Silne poczucie identyfikacji z chrześcijaństwem i kulturą europejską tłumaczą niektóre ich zachowania i decyzje. $Z$ dzisiejszego punktu widzenia możemy powiedzieć, że zachowania te byly błędną reakcją na pojawiające się problemy (maladaptive) i w ostatecznym rozrachunku kosztowały ich życie.

Grenlandia przyjęła chrześcijaństwo ok. roku 1000 p.Ch.n. - mniej więcej w tym samym czasie co Norwegia i Islandia oraz inne atlantyckie kolonie Wikingów. Przez ponad 100 lat grenlandzkie kościoły były stosunkowo nie-

51 Por. 凶. McGovern, The Archaeology of the Norse North Atlantic, art. cyt., s. 342.

52 Por. H. Pringle, Death in Norse Greenland, art. cyt., s. 924.

53 Por. J. Diamond, Collapse, dz. cyt., s. 252. 
wielkie, a do ich budowy używano torfu i kamienia. Zwykle wznoszono je tylko na większych farmach. Około roku 1118 Einar Sokkason został wysłany przez Wikingów do Norwegii w celu przekonania króla do zatroszczenia się o biskupa dla Grenlandii. Misja zakończyła się sukcesem a pierwszym biskupem rezydującym na Grenlandii został Arnald, po nim było jeszcze 9 innych biskupów. Bez wyjątku wszyscy oni byli urodzeni w Europie i tam uzyskali wykształcenie. Nie jest więc dziwne, że patrzyli na zwyczaje europejskie jako wzorzec swojego postępowania i przedkładali je nad lokalne zwyczaje. Np. preferowali wołowinę nad mięso fok i zachęcali do wypraw myśliwskich na północ w celu zdobycia środków potrzebnych do wymiany handlowej. Đylko w ten sposób byli w stanie uzyskać dobra niezbędne do kultu: wino mszalne, szaty liturgiczne, księgi i inne sprzęty kościelne a nawet witraże i dzwony kościelne. ${ }^{55}$

Biskup Arnald został wysłany do Grenlandii przez Sigurda Jorsalfara króla Norwegii w 1124 r. Przez długi czas odmawiał jednak objęcia stolicy wymawiając się kłótliwością i porywczością Wikingów. Ostatecznie zgodził się przyjąć godność biskupa Grenlandii pod warunkiem gwarancji bezpieczeństwa potwierdzonej przysięgą złożoną przez Einara Sokkasona - syna jednego z grenlandzkich wodzów. Einar zobowiązał się bronić nietykalności biskupa oraz dóbr kościelnych. Pomimo licznych niebezpieczeństw ze strony swych diecezjan biskup Arnald zmarł śmiercią naturalną. Uratował się jednak tylko dzięki sprawności politycznej i sprytowi, czego dowodem jest Saga o Einarze Sokkasonie. ${ }^{56}$

Wraz z przybyciem na Grenlandię pierwszego biskupa, Wikingowie zaczęli budowę kościołów. $Z$ małymi przerwami prace budowlane trwały praktycznie do około roku 1300 . Wzniesiono w tym czasie katedrę, 13 dużych kościołów oraz wiele małych świątyń a nawet klasztor. Większość kościołów była zbudowana na podbudowie kamiennej, natomiast ściany były konstruowane z torfu. छylko kościół Hvalsey i trzy inne grenlandzkie świątynie w całości zbudowano z kamienia. Kościoły te były niewspółmiernie duże w stosunku do potrzeb społeczności, które je budowały i utrzymywały. Np. katedra św. Mikołaja w Gardarze miała $32 \mathrm{~m}$ długości i $16 \mathrm{~m}$ szerokości, była tak duża jak katedry na Islandii, gdzie populacja wiernych była dziesięciokrotnie większa. Gardarską katedrę zbudowano z bloków kamiennych ważących nawet po 3 tony, które trzeba było transporto-

54 Por. \amże, s. 252; por. także 囚. H. McGovern, G.F. Biegelow, 冈. Amorosi, D. Russell, Northern Islands, Human Error, and Environmental Degradation, art. cyt., s. 108, 120-121. Inne poglądy na temat erozji gleb oraz jej przyczyn przedstawia G. K. Rutherford. Na podstawie przeprowadzonych badań chemicznych i mineralogicznych uważa, że nie ma podstaw do twierdzenia, że Wikingowie wyjałowili gleby, które nie były w stanie wydawać plonów na dotychczasowym poziomie. Por. G. K. Rutherford, Soils of Some Norse Settlements in Southwestern Greenland, art. cyt., s. 327.

55 Por. J. Diamond, Collapse, dz. cyt., s. 243.

56 Por. 冈amże, s. 236-237. 
wać z terenów odległych o kilka kilometrów. Przed domem biskupa ustawiono blok skalny ważący ok. 10 ton oraz wybudowano wieżę dzwonniczą o wysokości przekraczającej $24 \mathrm{~m}$ a także salę ceremonialną o powierzchni $130 \mathrm{~m}^{2}$ (największe pomieszczenie w ówczesnej Grenlandii). Niemal takich samych rozmiarów były 2 katedralne obory (jedna $\mathrm{z}$ nich mierzyła ponad $63 \mathrm{~m}$ długości). ${ }^{57}$

Na budowę kościołów oraz katedry zużyto wielkie ilości drogocennego drewna oraz mnóstwo bezcennego czasu niezbędnego do samej budowy oraz polowania w celu uzyskania środków na zakup materiałów i wyposażenie tych monumentalnych budowli. Ponadto wydatki związane z kupnem dzwonów, wina i innych przedmiotów kultu pochłaniały wszystkie dostępne środki, które można było przeznaczyć na zakup tak potrzebnych narzędzi pozwalających rozwinąć nowe technologie rolnicze i techniki myśliwskie. Wikingowie jako zadeklarowani chrześcijanie, podobnie jak wszyscy inni wierni, płacili Stolicy Apostolskiej dziesięcinę oraz podatek na wyprawy krzyżowe. ${ }^{58}$

\section{Czynniki mistyczne}

Wśród przyczyn upadku cywilizacji Joseph \ainter wymienia czynniki mistyczne. Wielu uczonych uważa, że przyczyną upadku cywilizacji Wikingów było przywiązanie do chrześcijaństwa. Wydaje się jednak, że takie ujęcie jest zbytnim uproszczeniem. Samo chrześcijaństwo jest tu raczej kryterium, jakie przyjęli grenlandzcy Normanowie, żeby odróżnić się od otaczających ich obcych społeczności. \o nie religijny fundamentalizm był przyczyną przeinwestowania sfery związanej z religią, ale raczej kulturowy europocentryzm, z którym Wikingowie utożsamiali chrześcijaństwo. Bliższa analiza ich decyzji wskazuje raczej na to, że religia była ekspresją ich europejskości, do której byli bardzo przywiązani, i za którą gotowi byli zapłacić bardzo wysoką cenę.

Jared Diamond charakteryzując mentalność Wikingów wskazuje, że były to społeczności o charakterze wspólnotowym, hierarchicznym, konserwatywnym, gwałtownym i europocentrycznym. Wszystkie te cechy są obecne u Wikingów

57 Por. 凶amże, s. 244; por. takż \. McGovern, The Archaeology of the Norse North Atlantic, art. cyt., s. 342. F. Fernandez-Armesto podaje, że w szczytowym okresie rozwoju w samym tylko mieście Brattahild znajdowało się 17 klasztorów i kamienne kościoły z dzwonami z brązu. Informacje te wydają się nieco przesadzone, jeśli weźmie się pod uwagę najnowsze badania wskazujące, że maksymalna populacja Wikingów zamieszkujących całą Grenlandię ledwie przekraczała 2 tys. osób. Brattahild było wprawdzie osadą założoną przez Eryka Rudego i należało do najbogatszych w Kolonii Wschodniej, jednak to Gardar był siedzibą biskupa. Por. F. Fernandez-Armesto, Cywilizacje. Kultura, ambicje i przekształcanie natury, Warszawa: PWN 2008, s. 50-52.

58 Daniny za okres 1274-1280 na rzecz krucjaty kosztowały ich 667 kg kłów morsów (z 191 zwierząt). Por. J. Diamond, Collapse, dz. cyt., s. 244. 
osiadłych na Islandii, Szetlandach i Wyspach Owczych. W przypadku Wikingów grenlandzkich, cechy te występują jednak w formie ekstremalnej. ${ }^{59}$

Ich gwałtowność i konserwatyzm miały ogromny wpływ na jakość relacji z sąsiadującymi ludami. ${ }^{60}$ Gwałtowność stała się także przyczyną niepowodzenia osadnictwa na terenie Ameryki. Konflikt z Indianami, w jaki bardzo szybko popadli, stał się bezpośrednią przyczyną opuszczenia przez Wikingów pierwszych osad amerykańskich. Podobnie przedstawiała się sytuacja $w$ relacjach $z$ Inuitami. Agresja i gwałtowność Wikingów nie pozwoliły na nawiązanie przyjaznych lub choćby poprawnych kontaktów, których brak okazał się kluczowy dla ich przetrwania.

Można przypuszczać, że oprócz ideologicznych (europocentrycznych) powodów wrogich stosunków z Inuitami w grę wchodziły także względy praktyczne, z powodu których nie było małżeństw mieszanych umożliwiających łatwe i skuteczne zapożyczenia kulturowe. Wiking nie mógł bowiem poślubić Inuitki, ponieważ nie potrafiła ona tkać, doić i oporządzać krów i przygotowywać sera na zimę. Nawet jeśli normandzki myśliwy zaprzyjaźniłby się z myśliwym inuickim, i tak nie był w stanie pożyczyć od niego skórzanej lódki i polować na foki, ponieważ łódki były robione na wymiar i tylko ich właściciele mogli z nich korzystać. $^{61}$

Wszystko wskazuje na to, że przepływ kulturowy między Wikingami i Inuitami dokonywał się tylko w jednym kierunku. Inuici zapożyczali pewne techniki od Wikingów, ale nie odwrotnie. Badania archeologiczne potwierdzają, że nie było między tymi ludami żadnych systematycznych kontaktów. McGovern podkreśla w tym względzie wagę przyczyn religijnych, z których - w jego opinii - miała wynikać tak wroga postawa chrześcijan-Wikingów do pogan-Inuitów. \akie ujmowanie zagadnienia wydaje się jednak zbytnim uproszczeniem, podobnym do tego, iż to religia była głównym powodem wojny na Bałkanach w końcu XX w. Wierność kulturze europejskiej i zamknięcie na kontakt $\mathrm{z}$ najbliższymi sąsiadami kosztowało Wikingów cenę biologicznego przetrwania. Woleli zjeść swoje ostatnie krowy, a nawet psy myśliwskie i umierać z głodu, podczas gdy Inuici polowali na obficie występujące w okolicy foki. Wikingowie nie zdobyli się jednak na zapożyczenie technik myśliwskich, które stosowali Inuici. ${ }^{62}$ Jest to o tyle dziwne, że dla Wikingów współpraca była koniecznością. Żaden pojedynczy Wiking ani nieliczna grupa rodzinna nie byli w stanie samodzielnie przetrwać na Grenlandii. \ym bardziej dziwne jest, że będąc skazani na współpracę w ramach swojej społeczności, nie nauczyli się współpracy z sąsiadującymi Inuitami. ${ }^{63}$

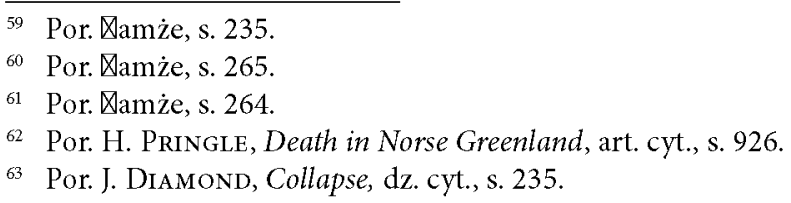


Konserwatyzm Wikingów był czymś wyjątkowym. Decyzja o wykluczeniu ryb z ich jadłospisu została podjęta najprawdopodobniej w bardzo wczesnym okresie kolonizacji Grenlandii. Pomimo zmieniającego się klimatu i narastających trudności ze zdobywaniem pożywienia. Przez ponad 450 lat nie zweryfikowali swojej decyzji i nie zmienili zdania! Nie próbowali też zmieniać swoich strategii myśliwskich przez zapożyczenie od Inuitów technologii oraz ich technik myśliwskich w polowaniu na foki i wieloryby. ${ }^{64}$

Wydaje się, ze jedynymi racjonalnymi powodami tłumaczącymi taką postawę, byly silne tendencje europocentryczne ujawniające się w przywiązaniu do chrześcijaństwa, które ostentacyjnie demonstrowali budując nieproporcjonalnie wielkie świątynie i przeznaczając znaczną część swoich zasobów ekonomicznych na przedmioty kultu religijnego. Wikingowie zaniedbywali jednocześnie inwestycje w narzędzia i technologie, które mogłyby znacząco wpłynąć na jakość ich życia.

\section{Zakończenie}

Podsumowując przyczyny upadku cywilizacji grenlandzkich Wikingów należy stwierdzić, że miało w tym przypadku miejsce nałożenie się wielu różnych czynników. Zmiany klimatyczne i oddalenie od Europy kontynentalnej to tylko część z nich. Nieracjonalna gospodarka powodująca degradację środowiska również przyczyniła się istotnie do nadchodzącej katastrofy. Najbardziej prawdopodobną przyczyną upadku społeczności grenlandzkich Wikingów były jednak czynniki kulturowe: separatyzm, konserwatyzm, europocentryzm oraz przemoc i porywczość, które uniemożliwiły im nawiązanie poprawnych relacji z sąsiednim ludem. Ich wybory kulturowe uniemożliwiły zapożyczenie od Inuitów ich technik myśliwskich i technologii dobrze sprawdzających się w subpolarnym klimacie. ${ }^{65}$

Błędem byłoby jednak obarczać winą jedynie czynniki kulturowe. Wydaje się, że ważną rolę w sposobie funkcjonowania społeczności grenlandzkich Wikingów odegrała polityka wewnętrzna oraz rozbieżność interesów elit i szeregowych członków ich społeczności. Władza znajdowała się w rękach świeckich przywódców oraz hierarchów kościelnych. Obie te grupy miały w posiadaniu większość gruntów, łodzie i kontrolowały handel z Europą. \o oni decydowali, co będzie importowane $z$ kontynentu. Decyzja ta $w$ dużej mierze zależała od prestiżu, jakiego miały te dobra przysporzyć ich właścicielom. Użyteczność i ekonomia odgrywały w tym względzie znacznie mniejszą rolę.

Można przypuszczać, że istniało wiele alternatyw dla zbliżającej się katastrofy, która wcale nie musiała dojść do skutku. Możliwe było sprowadzenie większej ilości żelaza i nowoczesnych narzędzi zamiast przedmiotów sakralnych i luksusowych dla elit. Przejęcie technik myśliwskich od Inuitów, wprowadzenie no-

64 Por. \amże, s. 239. 
wego rodzaju łodzi, mniej wypraw myśliwskich na północ, a więcej wypraw po drewno i żelazo do Ameryki. Zmiany takie mogły jednak zagrozić prestiżowi i partykularnym interesom klasy rządzącej. W społeczności znajdującej się na granicy przetrwania o wiele łatwiej było sprawować niepodzielną władzę. Elity były więc zainteresowane doprowadzeniem społeczności na granicę kruchej równowagi i utrzymywać ją w takim stanie. Zapożyczenie technik myśliwskich od Inuitów dałoby podstawy niezależności nawet małych grup rodzinnych. Wakie grupy mogłyby całkowicie oprzeć swoją egzystencję na myślistwie i przenosić się z miejsca na miejsce zależnie od pory roku i wędrówki zwierząt. Nie potrzebowatyby też ziemi będącej w posiadaniu lokalnych przywódców. Đakie zmiany społeczne zmarginalizowałyby znaczenie elit oraz ich władzę i stan posiadania.

Wydaje się, że w przypadku grenlandzkich Wikingów miał miejsce klasyczny konflikt interesów: krótkotrwałych interesów elit i dalekosiężnych interesów całej społeczności. Postawę taką wspierał ich konserwatyzm oraz przywiązanie do tradycyjnych sposobów zdobywania środków do życia oraz relacji społecznych. Wikingowie przybyli na Grenlandię z bagażem doświadczeń kulturowych oraz ukształtowanymi wartościami i przekonaniami. Sami uważali się za rolników, chrześcijan i Europejczyków. W tym kontekście należy rozpatrywać ich upodobanie do hodowli krów, ważność wypraw myśliwskich na północ oraz budowę świątyń, choć z punktu widzenia ekonomii nie były to zachowania opłacalne. Wikingowie, podobnie jak inni średniowieczni mieszkańcy Europy, uważali się za lepszych od pogan i plemion pozaeuropejskich. 冈łumaczy to dlaczego nie chcieli uczyć się od Inuitów i zachowywali się wobec nich wrogo. ${ }^{66}$

Patrząc z perspektywy współczesnego człowieka dziwimy się, że nie dostrzegli nadchodzącej zagłady. Wikingowie nie byli jednak w stanie zauważyć, stopniowo choć systematycznie, dokonujących się zmian. Długość życia człowieka oraz stan wiedzy na temat mechanizmów rządzących zmianami klimatycznymi i środowiskowymi nie pozwalały dostrzec zbliżającego się niebezpieczeństwa.

Nie znamy dokładnej daty śmierci ostatnich normandzkich osadników na Grenlandii. Ostatni europejski statek, który przywiózł im towary, zawinął do Grenlandii w roku 1410 . Kiedy w latach $1576-1587$ ponownie przybyli tam Europejczycy zastali wymarłe osady. ${ }^{67}$ Istnieje wiele hipotez na temat zniknięcia grenlandzkich Wikingów. Najbardziej prawdopodobne mówią o ich wymarciu. Są jednak i tacy, którzy uważają, że podobnie jak ich przybycie na Grenlandię było spowodowane szukaniem nowych obszarów do osiedlenia się, tak i wyczerpanie się naturalnych zasobów mogły skłonić ich do opuszczenia swoich grenlandzkich domostw i stopniowej emigracji w poszukiwaniu bardziej przyjaznych europej-

65 Por. H. Pringle, Death in Norse Greenland, art. cyt., s. 925-926.

66 Por. J. Diamond, Collapse, dz. cyt., s. 275-276.

67 Por. 冈amże, s. 271. 
skich terenów wyludnionych z powodu panujących epidemii. Początki odpływu młodych mieszkańców Grenlandii mogły mieć miejsce w pierwszych dekadach XIV wieku. Emigracja ta mogła przyczynić się do załamania kruchej równowagi demograficznej. Możliwy jest także scenariusz głoszący, że u schyłku Kolonii Wschodniej reszta pozostałych przy życiu Wikingów opuściła Grenlandię udając się w kierunku Islandii, Wysp Owczych, Szetlandów lub jeszcze innych terenów nie pozostawiając żadnych śladów swojej decyzji. ${ }^{68}$

Analiza przyczyn upadku grenlandzkich Wikingów powinna nas skłonić do rozwagi i ostrożności w obserwacji środowiska naturalnego oraz ograniczonego zaufania do polityków, których osobiste interesy i interesy ich partii stają często w sprzeczności z interesami lokalnych wspólnot, państw czy społeczności globalnej. Wydaje się, że także dziś wielu członków współczesnych elit jest w duchu przekonanych, że „im gorzej tym lepiej”. Sytuacje zagrożenia dają im bowiem możliwości antagonizowania poszczególnych grup społecznych lub narodowych i osiągania dzięki temu osobistych korzyści. Stwarzanie poczucia zagrożenia stanowi silny argument służący przekonaniu całych społeczeństw do samoograniczeń na różnych płaszczyznach.

Lekcja, której udzielili nam Wikingowie powinna nas skłonić do szerokiego otwarcia się na pomysłowość i wynalazczość każdej ludzkiej kultury, która może posiadać odpowiedzi na problemy, wobec których stajemy dziś lub które pojawią się w przyszłości. Otwartość i współpraca stanowią najważniejszy czynnik gwarantujący nam wszystkim bezpieczną przyszłość. Coraz wyraźniej zauważalne zjawisko globalizacji niesie ze sobą wiele niebezpieczeństw, jest jednak także gwarantem wymiany doświadczeń społeczności bardzo odległych terytorialnie i mentalnie. Z globalizacją łączy się kwestia troski o zachowanie kulturowej i biologicznej różnorodności. Unifikacja kulturowa i zubożenie bioróżnorodności może pozbawić nas możliwości adekwatnych odpowiedzi na problemy, które pojawią się w przyszłości. Procesy globalizacyjne przyczyniają się bowiem do unifikacji kulturowej i zawężają spectrum ujęć danego problemu oferowanych przez różne kultury.

Unifikacja kulturowa wpływa pośrednio na środowisko naturalne poprzez kreowanie jednakowych gustów i potrzeb, co z kolei wymusza na gospodarce wykorzystywanie podobnych zasobów w celu dostarczania oczekiwanych dóbr i usług. Przyczynia się to do uszczuplania bioróżnorodności i poświęcania coraz to większych terenów na uprawy roślin potrzebnych do produkcji modnych i pożądanych w danym okresie dóbr. Ceną takiej postawy może być nieodwracalna strata różnorodności gatunków flory i fauny lub zniszczenie ekosystemów, gdzie one żyją.

Wydaje się, że należy podjąć większy wysiłek zmierzający do uświadomienia mediom ich odpowiedzialność za kształtowanie wzorców zachowań, rozsądnego

68 Por. N. Lynnerup, Paleodemography of the Greenland Norse, art. cyt., s. 133-134. 
poziomu konsumpcji oraz postaw przyjaznych środowisku naturalnemu. Jest to o tyle trudne, że wolny rynek i chęć szybkiego zysku powoduje, iż wielkie koncerny inwestują ogromne fundusze w pobudzanie „apetytu” na dobra zbędne. Media nie są w tym procesie bezstronne, ponieważ zarabiają krocie na reklamach najprzeróżniejszych produktów.

Nadzieją napawa wprowadzanie w życie idei zrównoważonego rozwoju, która kompleksowo traktuje zagadnienia środowiska naturalnego, ekonomii i potrzeb człowieka. Inicjatywy legislacyjne Unii Europejskiej i różnego rodzaju porozumienia międzynarodowe na rzecz środowiska także skłaniają do optymizmu. Nie brak jednak wielu niepokojących oznak. Hans Jonas twierdzi, że wraz z rosnącymi możliwościami technicznymi człowieka i coraz dalej sięgającymi skutkami jego decyzji, rośnie także odpowiedzialność człowieka ${ }^{69}$ Nasza władza nad przyrodą powinna nas skłaniać do tym większej rozwagi w podejmowaniu decyzji. Każda z nich może bowiem przyczynić się do ostatecznej hossy lub bessy na skalę globalną. W przypadku współczesnego człowieka stawka tych wyborów jest znacznie wyższa niż w przypadku grenlandzkich Wikingów. Współczesny człowiek, inaczej niż w średniowieczny mieszkaniec Grenlandii, nie będzie miał bowiem możliwości przeniesienia się na inne tereny, by tam kontynuować życie swojej cywilizacji.

\title{
Collapse of greenland norse civilization. Influence of cultural factors
}

\author{
SUMMARY
}

Understanding collapse of ancient civilizations is important to understand very complex process happening in our civilization. The Earth is put in danger because of many reasons, and some of them do not change throughout the history. Because of global range of human actions, the power reached by contemporary man is much more dangerous than used to be centuries ago. Therefore, understanding the past collapses is crucial for the safety of our global village.

Article shows the reasons which caused the collapse of Greenland Norse civilization. It seems, that main reason was the climate change, but it also seems that Greenland Nose could had survived, or at least postponed the collapse. Author indicates that cultural factors were the roots of ecological degradation and the lack of economic adaptation. The Norse knew the Inuit and their adaptive strategies, but did not learn from them. It seems that the collapse of Greenland Norse civilization was caused by choice of the Norse's elite. The leaders kept the society in risky balance in order to rule over them, but finally the fragile equilibrium was shattered and caused the collapse.

69 Por. H. Jonas, Zasada odpowiedzialności. Etyka dla cywilizacji technologicznej, Kraków: Wydawnictwo Platan 1996. 